\title{
EKSEGESIS 1 KORINTUS 11:2-16 DAN IMPLIKASINYA TERHADAP ETIKA BERBUSANA DALAM IBADAH DARING DI MASA PANDEMI COVID-19
}

\author{
Boydo Rajiv Hutagalung \\ Gereja Protestan di Indonesia bagian Barat \\ rev.boydo@gmail.com
}

\begin{abstract}
Online Worship is a very prominent religious practice, especially during the Covid-19 Pandemic. One of the practical issues that arise when people worship at home, either alone or with a limited number of families, whether it is proper to wear clothes that are not as neat and formal as when worshiping in a church building? This article examines how the ethics of dressing in online worship can be interpreted based on the exegesis of I Corinthians 11: 2-16. The author uses the method of exegetical analysis to obtain the contained textual or socio-historical meaning. The author finds Paul's thinking about worship to be orderly and politely, including in relation to clothing. Besides that, Paul argues that in worship not only humans are present but also angels. Therefore, in online worship there is also the presence of God who should be respected with clothing and attitudes that are polite and appropriate.
\end{abstract}

Keywords: Online Worship; Pandemic; Ethics; Dressing; Modesty

\begin{abstract}
ABSTRAK
Ibadah secara daring merupakan praktik keagamaan yang sangat menonjol khususnya di masa Pandemi Covid-19. Salah satu isu praktis yang muncul saat orang-orang beribadah di rumah, baik sendirian ataupun bersama keluarga dalam jumlah terbatas, ialah apakah wajar saja untuk menggunakan busana yang tidak sama rapi dan formalnya dengan saat beribadah di gedung gereja? Artikel ini mengkaji tentang bagaimana etika berbusana dalam ibadah daring dapat dimaknai berdasarkan eksegesis I Korintus 11:2-16. Penulis menggunakan metode analisis eksegesis untuk memperoleh makna tekstual ataupun sosio-historis yang terkandung. Penulis menemukan pemikiran Paulus mengenai ibadah haruslah berlangsung secara teratur dan sopan, termasuk dalam kaitannya dengan busana. Selain itu, Paulus berpendapat bahwa dalam peribadahan, bukan hanya manusia yang hadir tetapi juga para malaikat. Oleh karenanya dalam ibadah online juga terdapat hadirat Allah yang sepatutnya dihormati dengan busana dan sikap yang sopan serta pantas.
\end{abstract}

Keywords: Ibadah Daring; Pandemi; Etika; Berbusana; Kesopanan

\section{PENDAHULUAN}

Tahun 2020 merupakan tahun yang penting di dalam sejarah dunia. Pada tahun tersebut, pandemi Covid-19 melanda seluruh dunia dan menjadi ancaman bagi kelangsungan hidup manusia. Virus itu muncul pertama kali secara lokal di Wuhan tetapi dengan cepat berubah menjadi ancaman global yang menewaskan banyak penduduk bumi. Penyebarannya yang sangat cepat membuat seluruh dunia menjadi wilayah pandemi. Infeksi terjadi bersamaan di hampir semua negara. Atas alasan inilah, maka pada 11 Maret 2020 badan kesehatan dunia WHO menetapkan bahwa Covid-19 telah menjadi global pandemic dan perlu penanganan yang sangat serius. Termasuk Indonesia, Presiden RI pada 13 April 2020 juga mengeluarkan Keputusan Presiden Nomor 12 Tahun 2020 bahwa penyebaran Covid 19 adalah bencana Nonalam yang berskala Nasional. ${ }^{1}$ Hingga Jumat 30 Oktober 2020, ada 45.278.676 orang di seluruh dunia yang ternifeksi, 1.185 .130 orang yang meninggal terinfeksi, dan 32.925 .700 orang yang sembuh. ${ }^{2}$

1 Mahatma Chrysna, Kepres Penetapan Wabah Covid-19 Sebagai Bencana Nasional, https://kompaspedia.kompas.id/baca/data/dokumen/keppres-penetapan-wabah-covid-19-sebagai-bencananasional, diakses 30 Oktober 2020

2 Mela Arnani, Update Corona Dunia: 45,2 Juta Kasus Positif, https://www.kompas.com/tren/read/2020/10/30/064800565/update-corona-dunia--45-2-juta-kasus-positif-rekorbaru-kasus-harian-global?page=all, diakses 30 Oktober 2020 
Hampir seluruh sektor kehidupan terdampak di masa Pandemi tersebut. Tak terluput kehidupan beragama di seluruh dunia, khususnya bagi Kekristenan. Pandemi Covid-19 memaksa gereja-gereja untuk memikirkan pola peribadahan dan aktivitas gerejawinya. Salah satu yang paling mencolok adalah pola ibadah Minggu yang dilakukan dari rumah masing-masing anggota jemaat. Hal ini cukup mengagetkan umat Kristen di Indonesia yang selama ini terbiasa beribadah Minggu dengan datang ke gereja.

Sebetulnya dalam sejarah Gereja perdana, peribadahan yang dilaksanakan di rumah-rumah adalah hal yang tidak asing. Kisah Para Rasul 2:46 mengatakan "Dengan bertekun dan dengan sehati mereka berkumpul tiap-tiap hari dalam bait Allah. Mereka memecahkan roti di rumah masing-masing secara bergilir dan makan bersama-sama dengan gembira dan dengan tulus hati." Menurut Wismoady Wahono, pada abad pertama umumnya jemaat Kristen asal Yahudi masih beribadah di Sinagoge, namun jemaat Kristen asal non-Yahudi cenderung melakukan ibadah yang dilaksanakan di suatu rumah. ${ }^{3}$ Sonny Eli Zaluchu mendeskripsikan bahwa pada masa jemaat mula-mula ibadah orang Yahudi untuk berdoa dan melakukan ritual keagamaan, hanya dilakukan di dalam Bait Allah. Namun demikian dalam perkembangannya, jemaat Kristen juga melakukan pertemuan dari rumah ke rumah untuk "memecahkan roti" atau jamuan makan bersama. ${ }^{4}$

Dalam beberapa rujukan lain di Alkitab, tampak bahwa corak gereja dan peribadahan waktu itu lebih merupakan gereja-rumah ketimbang gereja-jemaah yang bergedung khusus. ${ }^{5}$ I Korintus 16:19, "...Akwila, Priskila, dan Jemaat rumah mereka menyampaikan berlimpah-limpah salam kepadamu."; dan juga Filemon 2, "dan kepada Apfia saudara perempuan kita dan kepada Arkhipus, teman seperjuangan kita dan kepada jemaat di rumahmu." Menurut Wahono baru abad ketiga masehi ada usaha jemaat Kristen untuk membeli tanah dan membangun gedung ibadah khusus. ${ }^{6}$

Meskipun sejarah menunjukkan bahwa jemaat abad pertama terbiasa beribadah bersama beberapa keluarga di rumah-rumah, namun dalam perekembangannya semakin hari ibadah menjadi lebih terbiasa dilakukan pada suatu gedung khusus. Hal inilah yang membuat jemaat masa kini merasa cukup canggung untuk melaksanakan ibadah Minggu di rumah masing-masing.

Dalam beribadah Minggu di rumah di masa pandemi, ada jemaat yang melaksanakannya secara mandiri dengan anggota keluarga sebagai pelayan ibadah. Hal ini terjadi misalnya di sebagian daerah atau konteks jemaat lokal yang kurang memadai untuk mengakses ibadah secara online. Selain itu, yang semakin banyak terjadi adalah jemaat yang beribadah Minggu secara online. Sangat banyak gereja yang harus "bermigrasi" ke dunia maya untuk melaksanakan berbagai peribadahannya. Ini adalah hal mengagetkan lainnya, khususnya bagi gereja-gereja tradisional yang tidak terbiasa melakukan pelayanan secara online. Ibadah dilakukan dengan membuka video ibadah yang sudah direkam terlebih dahulu oleh pihak gereja dan dibagikan melalui platform tertentu atau pun melalui livestreaming yang dilakukan oleh gereja sehingga anggota jemaat dapat mengaksesnya menggunakan platform tertentu. Di sini terdapat suatu paradoks yang unik. Sebelum pandemi, jemaat disarankan untuk menonaktifkan gawainya agar tidak mengaggu fokus saat ibadah berlangsung, namun saat pandemi terjadi, jemaat justru menggunakan gawai tersebut untuk beribadah online dari tempat mereka masing-masing.

Perubahan pola peribadahan Minggu tersebut memunculkan berbagai pertanyaan baik yang bersifat praktis, etis, ataupun teologis. Dalam tulisan ini, penulis menyoroti isu etis yang muncul seiring dengan perkembangan ibadah online. Isu tersebut berkaitan dengan etika berpakaian selama mengikuti ibadah online. Dalam sebuah webinar yang pernah penulis ikuti, ada seorang peserta yang menanyakan, "Apakah saat beribadah online kita harus menggunakan pakaian yang formal seperti ibadah ke gereja sebelum masa pandemi?"

\footnotetext{
${ }^{3}$ S. Wismoady Wahono, Di Sini Kutemukan : Petunjuk Mempelajari dan Mengajarkan Alkitab (Jakarta : BPK Gunung Mulia, 2009), 460

4 Sonny Eli Zaluchu, "Eksegesis Kisah Para Rasul 2:42-47 untuk Merumuskan Ciri Kehidupan Rohani Jemaat Mula-mula di Yerusalem", EPIGRAPHE: Jurnal Teologi dan Pelayanan Kristiani, Vol 2 No. 2, (November 2018), 77

${ }^{5}$ Wahono, Di Sini Kutemukan, 460

${ }^{6}$ Ibid.
} 
Isu ini ternyata juga diangkat dalam beberapa video panduan beribadah online dari beberapa gereja. Perihal sikap tubuh dan busana yang layak digunakan saat beribadah secara online adalah hal yang turut menjadi himbauan, baik secara eksplisit ataupun implisit. Secara kreatif, video berjudul "Panduan Mengikuti Ibadah Online" memparodikan seorang muda dalam melaksanakan ibadah online dengan busana yang jauh dari terlihat rapi pada umumnya dan bahkan menjalankan ibadah online sambil mengerjakan hal-hal lain yang tidak terkait dengan ibadah. ${ }^{7}$

Beberapa video lain memberikan narasi yang jelas tentang pentingnya berpakaian yang rapi bahkan formal. Misalnya dalam video berjudul "Petunjuk Praktis Mengikuti Misa via Online Keuskupan Agung Jakarta", pada poin pertama dinyatakan "Persiapkan diri anda sebaik-baiknya. Bersih, rapi, dan berpakaian pantas sekalipun tidak harus formal. Persiapkan juga batin anda, seperti layaknya mengikuti misa di gereja." 8 Dalam video berjudul "Panduan Ibadah Online GBT Alfom Dan Yepo", dapat didengarkan panduan dari gembala jemaat tang mengatakan, "Yang kedua, jemaat mempersiapkan hati di dalam ibadah tersebut dengan memakai baju yang resmi, yang sopan karena sama seperti kita datang ke rumah Tuhan." Ada pula dalam video berjudul "Sikap Saat Ibadah Online", narator menyampaikan, "Siapkan diri dengan menggunakan pakaian yang pantas, rapi, dan sopan sama seperti akan beribadah ke gereja....duduklah dengan sopan, jangan berbaring ataupun melakukan aktifitas lainnya." ${ }^{10}$ Demikian pula gereja lainnya, dalam video berjudul "Panduan Ibadah Online", sang narator berkata, "siapkan diri dengan berpakaian rapi dan sopan sebagaimana kita beribadah di gedung gereja....silahkan duduk dengan posisi yang baik dan fokus"11

Mencermati hal ini penulis tertarik untuk melakukan penelusuran lebih jauh mengenai bagaimana perspektif alkitab mengenai etika dalam hal berbusana. Setidaknya ada beberapa bagian Alkitab yang memiliki persinggungan dengan topik busana. Di antaranya :

- Ulangan 22: 5 "Seorang perempuan janganlah memakai pakaian laki-laki dan seorang laki-laki janganlah mengenakan pakaian perempuan, sebab setiap orang yang melakukan hal ini adalah kekejian bagi TUHAN, Allahmu."

- Yehezkiel 44: 17, "Maka kalau mereka hendak masuk dari pintu-pintu gerbang pelataran dalam, mereka harus mengenakan pakaian lenan; mereka tidak boleh memakai pakaian bulu domba waktu mereka bertugas di pintu-pintu gerbang pelataran dalam atau waktu menyelenggarakan kebaktian dalam Bait Suci. Mereka harus memakai destar lenan dan memakai celana lenan, tetapi jangan memakai ikat pinggang yang menimbulkan keringat."

- I Korintus 11:6, "Sebab jika perempuan tidak mau menudungi kepalanya, maka haruslah ia juga menggunting rambutnya. Tetapi jika bagi perempuan adalah penghinaan, bahwa rambutnya digunting atau dicukur, maka haruslah ia menudungi kepalanya."

- I Timotius 2:9-10, "Demikian juga hendaknya perempuan. Hendaklah ia berdandan dengan pantas, dengan sopan dan sederhana, rambutnya jangan berkepangkepang, jangan memakai emas atau mutiara ataupun pakaian yang mahalmahal,tetapi hendaklah ia berdandan dengan perbuatan baik, seperti yang layak bagi perempuan yang beribadah"

- I Petrus 3:3-5, "Perhiasanmu janganlah secara lahiriah, yaitu dengan mengepangngepang rambut, memakai perhiasan emas atau dengan mengenakan pakaian yang indah-indah, tetapi perhiasanmu ialah manusia batiniah yang tersembunyi

\footnotetext{
7 "Panduan Mengikuti Ibadah Online", dalam https://www.youtube.com/watch?v=NM3LNdUQpYg, diakses pada 25 Januari 2021

8 "Petunjuk Praktis Mengikuti Misa Via Online - Keuskupan Agung Jakarta", dalam https://www.youtube.com/watch?v=nD9R8ldnfTE, diakses pada 25 Januari 2021.

9 "Panduan Ibadah Online Gbt Alfom Dan Yepo", dalam https://www.youtube.com/watch?v=hjj2uBgRgUE, diakses 25 Januari 2021.

10 "Sikap Saat Ibadah Online", dalam https://www.youtube.com/watch?v=yNOuaVq7bss, diakses 25 Januari 2021.

11"Panduan Ibadah Online", dalam https://www.youtube.com/watch?v=akM9CTB4H04, diakses 25 Januari 2021.
} 
dengan perhiasan yang tidak binasa yang berasal dari roh yang lemah lembut dan tenteram, yang sangat berharga di mata Allah. Sebab demikianlah caranya perempuan-perempuan kudus dahulu berdandan, yaitu perempuan-perempuan yang menaruh pengharapannya kepada Allah; mereka tunduk kepada suaminya,..."

Tentunya ayat-ayat di atas memiliki konteks dan makna hermeneutisnya masing-masing. Namun setidaknya beberapa rujukan tersebut menunjukkan bahwa hal berbusana baik dalam konteks ibadah ritual ataupun keseharian juga menjadi perhatian dalam sejarah Israel dan Kekristenan mulamula. Dari antara keempat rujukan ayat tadi, Surat Korintus yang menjadi fokus kajian penulis, khususnya pada perikop I Korintus 11:2-16.

Melalui tulisan ini penulis ingin menjawab 2 pertanyaan: (1) bagaimana persoalan busana dalam beribadah dipahami melalui penafsiran terhadap perikop I Korintus 11:2-16? (2) Bagaimana tinjauan eksegesis tersebut dapat dimaknai dalam konteks etika beribadah online di masa Pandemi?

\section{TINJAUAN PUSTAKA}

Asni Darmayanti Duha dalam artikelnya membahas mengenai bagaimana perkembangan zaman dan teknologi juga memengaruhi etika berpakaian dalam peribadatan, khususnya bagi kaum perempuan. ${ }^{12}$ Duha menyoroti fenomena tersebut dengan melakukan eksegese perikop I Timotius 2:910. Ia memaparkan bahwa Rasul Paulus memberikan pesan pastoral kepada Timotius untuk mengajarkan kepada kaum perempuan Kristen agar dalam beribadah hendaknya

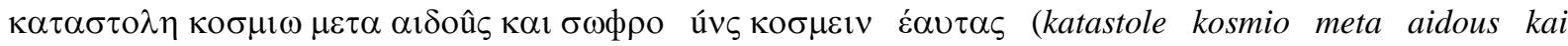
sophrosunes) yang oleh TB-LAI diterjemahkan "berdandan secara pantas, sopan dan sederhana/mengendalikan diri".

Penekanan pada aspek "kesopanan" yang dimaksud rujukan ayat-ayat tersebut secara harfiah berkaitan dengan kata $\pi \lambda \dot{\varepsilon} \gamma \mu \alpha \sigma ı v$ (plegmasin) yang diterjemahkan oleh TB-LAI "rambut berkepangkepang." Paulus menekankan agar jemaat perempuan di sana mengepang-ngepang rambutnya. Mengapa? Duha mengutip J. Wesley Brill yang mengatakan bahwa rambut yang berkepang-kepang (termasuk mengenakan perhiasan dari emas atau mutiara) pada masa itu adalah khas dari wanita tuna susila. $^{13}$

Sementara itu penekanan pada aspek "kesederhanaan" tampak pada penggunaan frase $\chi \rho \nu \sigma \iota \omega, \eta \dot{\eta} \mu \alpha \rho \gamma \alpha \rho \iota \tau \alpha \iota \varsigma \eta \dot{~ I ~} \mu \alpha \tau \imath \sigma \mu \omega \pi \mathrm{o} \lambda \nu \tau \varepsilon \lambda \varepsilon \iota$ (chrusio e margaritais e himatismo polutelei) yang oleh TB-LAI diterjemahkan "emas atau mutiara ataupun pakaian yang mahal-mahal". Menurut Duha, emas dan mutiara yang disebutkan oleh Paulus tampaknya juga berkaitan dengan rambut yang berkepang-kepang atau dengan kata lain perhiasan rambut yang terbuat dari emas dan mutiara. ${ }^{14}$ Sedangkan pakaian yang disoroti oleh Paulus adalah pakaian yang sangat mahal. ${ }^{15}$ Dengan demikian Paulus mengajarkan agar dalam beribadah sebaiknya hal-hal yang merupakan dandanan yang mewah sebaiknya tidak digunakan. Paulus menghendaki etika kesopanan dan kesederhanaan menjadi bagian penting dalam kehidupan peribadahan umat.

Selanjutnya kajian Duha didialogkan dengan konteks peribadahan kekinian. Duha menggarisbawahi bawah perkara apa yang dipandang sopan, sederhana dan pantas adalah bersifat relatif dan disesuaikan dengan konteks di mana seseorang berada. ${ }^{16}$ Namun demikian, ia berpendapat bahwa di era modern ini, semakin banyak kaum perempuan yang kurang mengindahkan aspek kesederhanaan dan kesopanan sebagaimana diatur dalam norma-norma masyarakat setempat terutama dalam beribadah khususnya di gereja. Padahal, menurut Duha, di satu sisi gereja adalah bait kudus yang selayaknya orang datang dengan mengindahkan norma kesopanan dan di sisi lain pakaian adalah cerminan martabat diri atau kepribadian seseorang. ${ }^{17}$

\footnotetext{
12 Asni Darmayanti Duha, "Etika Berpakaian bagi Kaum Perempuan Dalam Ibadah Menurut I Timotius 2:9-10 dan Aplikasinya Masa Kini”, Jurnal Teologi Berita Hidup, Vol.2 No.2, (Maret 2020), 155-171

${ }^{13}$ Ibid., 161

${ }^{14}$ Ibid.

${ }^{15}$ Ibid.

${ }^{16}$ Ibid., 168

${ }^{17}$ Ibid., 169
} 
Kajian lain dilakukan oleh Nurul Farahiyah Binti Abu Bakar yang mencoba membandingkan etika berbusana dalam ajaran Islam dan Kristen serta mengutarakan perbedaan dan juga persamaan di antara keduanya. ${ }^{18}$ Dengan mengutip William Thourlby, Farahiyah menguraikan bahwa agama Kristen juga memilki prinsip terkait berpakaian dan mengenakan perhiasan sebab penampilan luar adalah suatu kesaksian terhadap sesama dan memiliki kaitan relasi antara seseorang itu dengan Tuhan. ${ }^{19}$ Namun demikian, menurut Farahiyah, adalah cukup langka pengajaran, khotbah dan literatur Kristen yang membahas isu pakaian dan perhiasan Kristen. Hal ini baginya mengindikasikan bahwa isu pakaian dan perhiasan tidak lagi dipandang sebagai indeks karakter Kristen yang penting, di mana banyak orang Kristen yang memiliki keyakinan bahwa orang Kristen tidak terbentuk dalam hal lahiriah atau beraggapan bahwa pakaian dan perhiasan tubuh mereka tidak ada hubungannya dengan spiritualitas. ${ }^{20}$ Ia juga berpendapat bahwa "relaksasi" atau melonggarnya prinsip Kristen dalam penggunaan pakaian atau perhiasan adalah dikarenakan pergeseran bertahap yang terjadi selama seabad terakhir, di mana pandangan materialistik menjadi sangat dominan. ${ }^{21}$

Perikop I Timotius 2.9-10 juga menjadi bagian yang disoroti oleh Farahiyah. Menurutnya ajaran Alkitab tersebut menekankan aspek kesopanan, kepantasan, dan kesederhanaan. Alkitab tidak melarang perempuan, khususnya, untuk menghiasi diri namun hal itu harus dipertimbangkan secara moral atau dengan pengendalian diri. Pakaian tidak hanya mencerminkan selera dan moralitas tetapi juga akan membentuk perilaku seseorang. ${ }^{22}$

Farahiyah mengemukakan penemuannya bahwa persamaan antara ajaran Islam dan Kristen ialah keduanya mengajarkan agar dalam berbusana seharusnya menggunakan busana yang menutup aurat, melarang untuk menggunakan busana lawan jenis. Sementara untuk perbedaannya, Farahiyah berpendapat bahwa etika berpakaian dalam Islam mengharuskan perempuan menutupi aurat mulai dari ujung rambut hingga ujung kaki, kecuali wajah dan telapak tangan. Sementara dalam Kristen, berdasarkan Alkitab, etika berpakaian, khususnya bagi perempuan ialah tidak ada kriteria spesifik mengenakan pakaian yang menutup aurat. Namun yang pasti ditekankan unsur kesopanan dan kesederhanaan, serta kesesuaian dengan kondisi lingkungan serta norma-norma yang berlaku. ${ }^{23}$

Melalui penelitian Duha dan Fahariyah, penulis mendapatkan gambaran yang cukup kuat khususnya terkait etika berbusana di antara jemaat mula-mula. Misalnya etika berbusana dalam beribadah pada konteks jemaat yang dilayani oleh Timotius menekankan pada aspek kepantasan, kesopanan, dan kesederhanaan. Tidak ada standar yang baku mengenai jenis dan fashion yang tepat untuk beribadah. Namun setidaknya, ada peringatan kepada jemaat Kristen untuk mewaspadai dandanan atau busana yang membuat orang mengidentikkan jemaat Kristen dengan perempuan tuna susila dan perempuan-perempuan kaya yang boros.

Akan tetapi dalam tulisan ini, penulis tidak akan menyoroti ibadah yang berlangsung secara onsite di gedung gereja atau pun tempat pertemuan jemaat di mana banyak keluarga hadir. Tulisan ini akan menyoroti peribadahan yang berlangsung secara online dan dilakukan di rumah masing-masing atau tempat masing-masing jemaat Kristen sedang berada, di mana hanya sangat terbatas anggota yang hadir untuk beribadah. Selain itu, jikalau Duha menyoroti perikop Alkitab dan juga konteks kekinian yang membahas aspek busana yang berpotensi mengarah pada indikasi asusila dan kesombongan, berbeda dengan penulis yang justru akan menyoroti fenomena beribadah online di rumah dengan busana yang cenderung mengesampingkan perlunya persiapan diri secara sopan, rapi, dan hormat. Selain itu penulis membatasi diri hanya pada perikop I Korintus 11:2-16.

\footnotetext{
${ }^{18}$ Nurul Farahiyah, "Etika Berbusana : Studi Kontemporer Antara Islam dan Kristen”, Skripsi, Fakultas Dakwah dan Komunikasi, Universitas Islam Negeri Ar-Raniry, 2018.

${ }^{19}$ Ibid., 43

${ }^{20}$ Ibid., 43-44

${ }^{21}$ Ibid.

${ }^{22}$ Ibid., 45-46

${ }^{23}$ Ibid., vii, 95
} 


\section{METODE}

Dalam tulisan ini digunakan metode eksegesis untuk memaparkan latar belakang sosio-historis dan juga menguraikan tafsiran terhadap beberapa kata kunci yang ditemukan dalam perikop yang akan dikaji. Studi dari beberapa referensi pustaka menjadi alat bantu dalam eksegesis.

\section{HASIL DAN PEMBAHASAN}

4.1. Konteks

Menurut M.E. Duyverman, salah satu keunikan jemaat Korintus ialah karena mereka sangat menghargai kebebasan pribadi dan karunia roh. Namun kekurangannya ialah, jemaat ini lemah dalam memelihara persatuan. Sebagai contoh persoalan persatuan jemaat di Surat Korintus ialah dalam hal makan daging yang sudah dipersembahkan kepada dewa (8:4,7,9-13). Sebenarnya sah-sah saja untuk memakan daging sekalipun sudah terlebih dulu dipersembahkan untuk dewa-dewi Korintus karena bagaimanapun orang Kristen tidak mengakui keberadaan dewa-dewi itu. Namun demikian masih ada sebagian anggota jemaat yang belum sampai pada keyakinan bahwa memakan persembahan kepada dewa itu diperbolehkan. Hal ini menimbulkan pertikaian dan saling melecehkan di antara jemaat. Oleh karenanya Paulus mengajarkan sikap toleransi terhadap mereka yang belum bisa menerima. Hal ini lebih baik dilakukan demi keutuhan persatuan jemaat. Contoh lain dari lemahnya persatuan jemaat Korintus ialah sikap tidak memelihara ketertiban dalam perjamuan $(10: 14-30 ; 11 ; 12 ; 14) .{ }^{24}$

Pasal 11 merupakan salah satu bagian yang berkesinambungan dari pasal $11-14$, yang menyoroti berbagai masalah berkaitan dengan kehidupan peribadatan jemaat Korintus. Paulus mendapatkan berita mengenai adanya kekacauan dalam pertemuan ibadah di antara jemaat Korintus. Salah satu dari beberapa masalah tersebut dibahas dalam pasal 11: 2-16. Menurut Duyverman, ada sikap yang keliru dalam kebaktian, di mana para perempuan yang sudah "bebas" di dalam Kristus. ${ }^{25}$

Pertama-tama, beberapa perempuan di Korintus memiliki karunia roh untuk berdoa dan bernubuat. Namun ada di antaranya yang yang membanggakan diri karena memiliki karunia Roh tersebut. Meskipun mereka diberikan ruang untuk berkata-kata dengan leluasa dalam kebaktian (I Kor. 14:34) namun mengakibatkan ibadah jemaat di Korintus berlangsung kacau dan ricuh. Hal inilah yang membuat Paulus menasihatkan agar peribadahan di atur dengan tertib dan sopan (I Kor. 14:26-40). ${ }^{26}$

Selanjutnya, para perempuan "berkarunia" itu membanggakan diri dan mulai menyalahi aturan berpakaian yang pantas dikenakan para perempuan di masa itu dalam ibadah. Mereka datang dalam kebaktian secara tidak bertudung (11:5). Padahal, perempuan yang tampil di depan umum dengan tidak bertudung pada zaman itu adalah para wanita penghibur kalangan elit (yun: hetaire). ${ }^{27}$

Kevin Schenk berpendapat ada sejumlah jemaat di Korintus yang menyalahartikan atau menyalahgunakan prinsip Kristen mengenai kesetaraan laki-laki atau pun perempuan. Prinsip ini merupakan ajaran dari Paulus yang dapat kita temukan dalam Galatia 3:28 yang menyatakan bahwa dalam Tuhan semuanya, baik orang Yahudi ataupun orang Yunani, kaum budak atau kaum merdeka, laki-laki atau perempuan adalah satu di dalam Kristus. ${ }^{28}$ Menurut Schenk prinsip ini tampaknya biasa dilafalkan pula dalam pembaptisan jemaat baru di zaman itu. Akan tetapi ada jemaat Korintus yang menerapkan prinsip tersebut di luar konteks dan pengertian yang tepat. Beberapa dari perempuan di jemaat Korintus mencoba memelintir prinsip kesetaraan tersebut untuk keluar dari kepemimpinan suaminya. Hal ini ditandai dengan tidak menggunakan penutup kepala ketika berhadapan dengan lakilaki lain. ${ }^{29}$ Di latar belakangi hal inilah maka Paulus harus kembali menegaskan mengenai perbedaan antara laki-laki dannghina kepalanya. Jadi, laki-la perempuan dalam berpakaian di masa itu. Bagi lakilaki yang kepalanya bertudung maka ia tidak boleh menudungi kepalanya saat beribadah. Sebaliknya bagi perempuan yang kepalanya tidak bertudung maka ia menghina kepalanya. Bahkan ditambahkan

\footnotetext{
${ }^{24}$ M.E. Duyverman, Pembimbing Ke Dalam Perjanjian Baru (Jakarta: BPK Gunung Mulia, 2009), 100.

${ }^{25}$ Ibid.

${ }^{26}$ Ibid.

27 Ibid.

${ }^{28}$ Kenneth Schenk, $1 \& 2$ Corinthians :A commentary for Bible Students (Indianapolis: Wesleyan Publishing House, 2006), 152

29 Ibid.
} 
perempuan yang demikian sama dengan perempuan yang dicukur rambutnya. Jadi, mereka harus memakai tudung.

\subsection{Eksegesis 1 Korintus 11: 2-16}

Pada ayat 2 Paulus memuji jemaat di Korintus karena mereka mengingat Paulus dan berpegang teguh pada ajaran yang diteruskan kepada mereka oleh Paulus. Pujian ini merupakan bentuk kesadaran yang coba Paulus bangun sebagai sebuah retorika untuk menarik pendengar dan mengembalikan fokus jemaat terhadap persoalan yang tak mereka sadari kembali, yakni persoalan di seputar penampilan para perempuan yang berdoa dan bernubuat dengan kepala tanpa tudung.

Pada ayat 3, Paulus menunjukkan semacam "rantai hierarki" yaitu : Allah - Kristus - Laki-laki - Perempuan. Menurut V.C. Pfitzner, pada ayat 3 penggunaan kata $\kappa \epsilon \phi \alpha \lambda \dot{\eta}$ (kefale) yang diterjemahkan TB-LAI "kepala" adalah simbolik dan bukan dalam arti anggota tubuh. Dalam pengertian simbolik, menurut Pfitzner "kepala" biasanya diasosiasikan dengan peran pimpinan, pemerintahan, sumber dari sesuatu. ${ }^{30}$

Pfitzner juga menguraikan lebih lanjut pemaknaan tentang "kepala" yang dimaksud oleh Paulus. Pertama, Allah adalah kepala dari Kristus. Untuk memahami hal ini kita perlu waspada sebab jika ditafsirkan bahwa "kepala" adalah dalam pengertian keunggulan atau kewibawaaan yang satu lebih besar dari yang lain, maka akan terjadi kontradiksi dengan Pengakuan Iman Nicea-Konstantinopel yang memuat gagasan bahwa "Sang Anak adalah sederajat dengan Sang Bapa dalam keilahian, kuasa, kehormatan, kewibawaan, dan kemuliaanNya." ${ }^{31}$ Meskipun ada kesan sub-ordinasi dalam I Kor. 3:23, 15:28, namun hal itu menurut saya bukan bermakna sub-ordinasi yang membedakan derajat atau kewibawaan Allah dan Kristus. Menurut saya hal itu bermakna Kristus, menempatkan diri sebagai Sang Anak dalam ketaatan yang bebas dan tidak terpaksa dalam menjalankan misi-Nya. Ikatan antara Bapa dan Anak adalah saling memiliki dan saling mengasihi.

Kedua, Kristus adalah Kepala dari tiap laki-laki dalam pengertian bahwa Kristus adalah perantara dari penciptaan laki-laki. Segala sesuatu diciptakan melalui Kristus (I Kor.8:6; Yoh.1:3; Kol.1:16; Ibr. 1:2 dan 2:10). Ketiga, Kristus juga merupakan kepala dari Gereja karena Kristus merupakan Juruselamatnya (Ef. 5:23-37). Keempat, Laki-laki adalah kepala dari perempuan dalam pengertian laki-laki adalah sumber penciptaan perempuan namun keduanya ada dalam dalam kesalingterkaitan (interdependensi). Makna yang ingin ditonjolkan dalam "ilustrasi rantai" itu, menurut Pfitzner, bukan soal "bos" atau "tuan" atau yang satu lebih berkuasa daripada yang lain. "Kepala" di sini dimaknai sebagai sumber atau asal-usul yang dengan demikian diharapkan agar terjadi sikap yang saling menghormati. ${ }^{32}$ Dalam artian inilah pemahaman bahwa kepala dari perempuan adalah laki-laki. Konteks yang melatarbelakangi pemaknaan tersebut ialah agar kaum perempuan yang "dipermasalahkan dalam sikap beribadah" di Korintus dapat menempatkan diri dan membangun sikap saling menghormati.

Schenk mengatakan bahwa hubungan hierarkis yang dimaksud Paulus adalah hubungan antara suami dan istri dan bukan untuk laki-laki dan perempuan secara umum. Sebab, menurut Schenk, tidak semua laki-laki adalah kepala dari perempuan. Akan tetapi yang pasti, dalam perspektif Paulus seorang suami adalah kepala bagi istrinya. Schenk mendasarkan argumennya pada kata Yunani spesifik yang

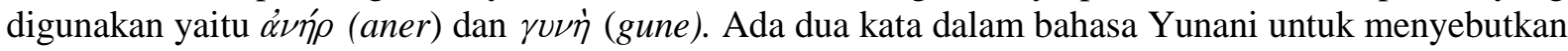
laki-laki maupun suami yaitu ávńp (aner) dan $\dot{\alpha} \nu \delta \rho o ̀ \varsigma$ (andros). Paulus senantiasa menggunakan katakata tersebut secara bergantian untuk menyebutkan "laki-laki pada umumnya" (andros) maupun untuk menyebutkan suami (aner). Sementara itu untuk menyebutkan "perempuan pada umumnya" maupun "istri" hanya ada menggunakan satu kata yaitu $\gamma v \nu \eta$. Pada perikop I Kor.12:3 yang digunakan adalah kata aner dan gune yang biasa digunakan dalam kaitannya terhadap hubungan antara suami dan istri. ${ }^{33}$

Sama dengan Pfitzener, Schenk mengusulkan kata "kepala" sebagai kekuasaan maupun sumber atau asal. Namun menurut Schenk, dengan mengatakan"kepala" sebagai "sumber", maka sebenarnya ia juga berarti "kekuasaan". Hal ini mengingat pemahaman kuno pada masa itu bahwa kepala sebagai

\footnotetext{
${ }^{30}$ Pfitzner, Kesatuan Dalam Kepelbagaian, 200

${ }^{31}$ Ibid., 200-201

32 Ibid., 200

${ }^{33}$ Schenk, $1 \& 2$ Corinthians. 153
} 
penguasa tubuh. Schenk memberi contoh pemikiran Plato ratusan tahun sebelum Kristus yang menjelaskan bahwa hubungan antara penguasa dan rakyatnya seharusnya adalah seperti kepala "kepada" seluruh tubuhnya. Demikian Schenk berpendapat bahwa seperti itulah hubungan antar suami sebagai kepala dari istri di sini, bahwa ada implikasi tingkatan dan kekuasaan. ${ }^{34}$

Pendapat lain dikemukakan oleh Marry Ann Getty yang berbeda dengan Schenk dalam melihat bahwa yang dimaksud oleh Paulus bukan antara suami dan istri tetapi memang antara laki-laki dan perempuan. Ia menekankan bahwa pokok yang dibahas oleh Paulus adalah mengenai pakaian laki-laki dan perempuan tanpa bermaksud membeda-bedakan peranan mereka dalam ibadah.Menurut Getty, Paulus menekankan harus ada perbedaan dalam pakaian ibadah namun tidak ada perbedaan dalam peranan liturgis. ${ }^{35}$ Apa yang menjadi argumen Getty tampak jelas dalam ayat 4-5, di mana Paulus menyebutkan bahwa laki-laki dan perempuan sama-sama diperbolehkan untuk berdoa dan bernubuat. Hal ini menandakan karunia roh diberikan tanpa memandang latar belakang jenis kelamin. Namun Paulus membuat pembedaan, yaitu laki-laki yang berdoa-bernubuat dengan kepala bertudung adalah menghina kepalanya dan sebaliknya perempuan yang berdoa-bernubuat tidak menudungi kepalanya juga menghina kepalanya.

Apakah makna "kepala" yang ditudungi? Ada kemungkinan Paulus menggunakan dua makna atau arti sekaligus dalam ayat ini. Yang satu adalah makna denotatif (sebenarnya) yaitu soal mengenakan tudung ataupun tidak bertudung. Yang kedua adalah makna konotatif (simbolik) seperti pada ayat 3 sebelumnya. Akan tetapi tampaknya yang dimaksudkan oleh ayat 4 dan 5 adalah soal penggunaan tudung atau penutup kepala dalam arti sebenarnya dan bukan kiasan.

Pertanyaan berikutnya, tudung seperti apa yang dimaksud oleh Paulus yang bisa membawa penghinaan jika dipakai oleh laki-laki atau jika tidak dipakai oleh perempuan? Schenk menuliskan ada tiga penafsiran terhadap tudung ini. ${ }^{36}$ Pertama, gagasan bahwa tudung yang dimaksud adalah rambut perempuan, yaitu antara rambut panjang dengan rambut yang pendek. Penafsiran ini didukung juga dengan pendapat Pfitzner bahwa ayat 4 sebenarnya mengatakan bahwa laki-laki bertindak tidak sopan jika ada sesuatu yang terjatuh dari kepalanya, yang bisa jadi rambut atau penutup kepala. Karena pada ayat-ayat selanjutnya Paulus memberi perbandingan tentang wanita yang tak bertudung sama dengan perempuan yang mencukur atau menggunting rambutnya. Belakangan Paulus juga menyinggung potongan rambut bagi laki-laki (ayat 14-15). Pfitzner juga mengatakan bahwa hal ini didukung oleh 1 Timotius 2:9 yang menasihati perempuan Kristen agar berdandan dengan sopan, dengan rambut yang tidak berkepang-kepang. ${ }^{37}$

Kedua, gagasan bahwa tudung yang dimaksud adalah sebuah penutup kepala seperti kerudung. Kerudung di dunia Timur sangatlah penting. William Barclay menjelaskan bahwa hingga hari ini perempuan Timur menggunakan Yasmak yaitu kerudung panjang terbuka di dahi dan mata tetapi menutupi seluruh tubuh yang lain hingga ke kaki. ${ }^{38}$ Barclay juga menjelaskan arti kerudung bagi dunia Timur. Pertama, kerudung merupakan tanda inferioritas (rendah diri). Namun juga arti kedua, kerudung merupakan sebuah perlindungan yang besar. Dengan menggunakan kerudung seorang perempuan akan sangat dihormati. Kerudung menjadi wibawa dan martabat bagi seorang perempuan. Sebaliknya wanita tanpa kerudung yang berjalan di depan umum mendapatkan image negatif dan sering dihina. Pada waktu itu untuk konteks Yahudi kuno mengindikasikan perempuan tuna susila. ${ }^{39}$

Ketiga, tudung yang dimaksud adalah tentang tata-rambut, yaitu antara rambut yang terikat dan ditutupi, atau rambut yang terurai. Adat Graeco-Roma memperhatikan potongan rambut dari perempuan. Melepaskan dan menggantungkan rambut adalah tanda dukacita. Rambut perempuan

\footnotetext{
${ }^{34}$ Schenk, $1 \& 2$ Corinthians, 154

${ }^{35}$ Marry Ann Getty, "I Korintus", terj. A.S. Hadiwiyata, Tafsir Alkitab Perjanjian Baru (Yogyakarta : Kanisius, 2002), 296

${ }^{36}$ Schenk, $1 \& 2$ Corinthians, 56

${ }^{37}$ Pfitzner, Kesatuan Dalam Kepelbagaian, 201

${ }^{38}$ William Barclay, Pemahaman Alkitab Setiap Hari : Surat 1 dan 2 Korintus (Jakarta : BPK Gunung Mulia, 2008), 176

${ }^{39}$ Alkitab: Edisi Studi (Jakarta: Lembaga Alkitab Indonesia, 2012), 1878.
} 
umumnya ditata dengan perawatan yang baik sekali. Ia dikepang dan dihias secara teratur, terkadang diberi hiasan yang cukup mahal. Hiasan rambut adalah tanda harkat dan martabat. ${ }^{40}$

Dari ketiga kemungkinan penafsiran terhadap tudung di atas, tampaknya yang paling mungkin adalah yang kedua yaitu tudung adalah sejenis kerudung. Kembali pada konteks pembicaraan Paulus yaitu tertuju pada peribadatan. Paulus harus menekankan pengenaan kerudung ini karena aktifitas peribadatan seperti berdoa dan bernubuat adalah dilakukan dalam komunitas dan bukan dilakukan secara pribadi. Hal ini juga berkaitan dengan sikap Paulus yang hendak meniadakan sikap individualistis yang ada di kalangan jemaat Korintus saat itu. ${ }^{41}$

Pada konteks jemaat Korintus saat itu, ada sebagian perempuan-perempuan atau istri-istri di jemaat yang tidak mengenakan kerudung ketika beribadah. Mungkin mereka ingin mengukuhkan bahwa di dalam Kristus, semuanya, laki-laki dan perempuan adalah sama. Akan tetapi faktanya, ketika mereka ada dalam konteks sosial masyarakat, keyakinan pada prinsip kesamaan yang diekspresikan dengan tidak menggunakan kerudung akan mempermalukan suami-suami mereka. Dengan tidak menutupi rambut mereka dengan kerudung mereka mengundang perhatian orang-orang di sekitar mereka karena budaya mereka tidaklah terbiasa dengan hal ini.

Ada konotasi negatif jika seorang perempuan bersuami tidak mengenakan kerudung yaitu kemungkinan bahwa perempuan tersebut adalah perempuan asusila. Selain itu budaya pada masa itu mengindikasikan bahwa rambut menjadi sesuatu yang sangat sensitif. Rambut selain bermakna mahkota dan keindahan seorang wanita ternyata juga diyakini sebagai organ yang dianggap mengandung nilai sensualitas dalam budaya Yunani. ${ }^{42}$ Dengan berbagai pertimbangan dan dampak sosial yang ditimbulkan inilah maka Paulus menganjurkan kepada laki-laki dan perempuan agar berpenampilan menurut kebiasaan setempat demi menjaga kesopanan dan berpakaian layak dalam perayaan ibadah.

Paulus juga memberikan analogi atau perbandingan bahwa perempuan yang tidak mengenakan tudung kepala adalah sama hinanya dengan perempuan yang dicukur rambutnya. Telah dijelaskan sebelumnya bahwa rambut adalah simbol kewibawaan seorang wanita. Jika ia tidak memiliki mahkota keindahannya itu maka ia tidak akan memiliki makna apa-apa lagi dalm konteks masyarakatnya. Pada ayat 6 Paulus menunjukkan bahwa satu-satunya cara jika ia tidak mau menudungi rambutnya adalah dengan menggunting atau mencukur rambutnya. Dalam masyarakat ketika itu, perempuan yang memendekkan rambutnya adalah mengindikasikan wanita tuna susila dan lesbian. Mencukur rambut adalah hukuman yang diberikan pada wanita tuna susila. ${ }^{43}$

Pada ayat ke 7 kembali lagi disampaikan bahwa laki-laki tidak perlu menudungi kepalanya. Alasan yang dikemukakan Paulus adalah karena laki-laki menyinarkan gambaran dan kemuliaan Allah. Oleh sebab itu ketika ia berdoa kepada Allah atau berbicara bagi-Nya, laki-laki harus membiarkan kepalanya terbuka, tidak tersembunyi. Menurut Getty, argumentasi ini berangkat dari konsep penciptaan yang dipahami oleh Paulus (I Kor.11:3-9) dan konsep Kristus adalah yang sulung dari segala ciptaan (Kol. 1:15). ${ }^{44}$

Sementara itu, dikarenakan perempuan berada di bawah kekepalaan laki-laki, maka ketika ia berdoa kepada Allah atau berbicara bagi Allah, ia harus menudungi kepalanya. Selain itu, Paulus juga menekankan bahwa jika perempuan membiarkan rambutnya tidak tertutupi, maka ini akan membawa penghinaan. Menurut Getty, rambut panjang dan penutup kepala wanita adalah tanda kewibawaan Allah atas mereka yang diperantarai oleh pria. ${ }^{45}$

Meskipun demikian adalah menarik melihat penggunaan kata pada ayat 7 ini. Dikatakan bahwa:

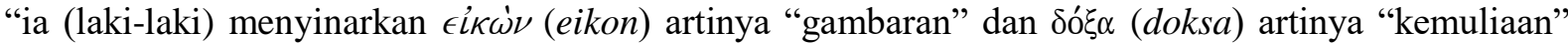
Allah. Tetapi perempuan menyinarkan kemuliaan laki-laki". Paulus tidak mengatakan perempuan adalah gambaran atau image dari laki-laki. Ini menunjukkan pengakuan Paulus bahwa perempuan tetap adalah gambaran Allah. Perempuan dikatakan menyinarkan kemuliaan laki-laki karena perempuan, "diciptakan bagi laki-laki". Hal ini dinyatakan oleh Paulus berdasarkan kisah penciptaan di kitab

\footnotetext{
40 James B. Hurly, Man and Woman In Biblical Perspective (Leicester: Inter-Varsity Press, 1981), 67

${ }^{41}$ Martina Novalina, Mengenal Paulus dan Teologinya (Bogor: CV. Lindan Bestari, 2020), 70.

${ }^{42}$ Schenk, $1 \& 2$ Corinthians, 153

${ }^{43}$ Getty, "I Korintus", 296

${ }^{44} \mathrm{Ibid}$.

${ }^{45}$ Ibid.
} 
Kejadian 2. Bukan dari kisah penciptaan di Kejadian 1. Ini dikemukakan pada ayat 8 dan 9. Laki-laki tidak berasal dari perempuan, karena Allah menciptakan laki-laki sebagai manusia pertama. Perempuan berasal dari laki-laki, karena Allah menciptakan perempuan dari tulang rusuk laki-laki. Lagipula, lakilaki tidak diciptakan karena perempuan, tetapi perempuan diciptakan karena laki-laki. Inilah yang diungkapkan pada Kejadian 2 yang mengisahkan bagaimana Adam tidak menemukan pendamping yang sepadan baginya sehingga Allah menciptakan bagi Adam seorang pendamping yang sepadan untuk menolongnya. Itulah Hawa sang perempuan (Kej.2:18).

Pada ayat 10 dikatakan bahwa perempuan harus memakai tanda wibawa di kepalanya karena para malaikat. Ada dua hal yang menarik yaitu tanda wibawa dan malaikat. Pertama, tanda wibawa dapat diartikan sebagai kerudung yang dikenakan perempuan di kepalanya. Cuppert memberi gambaran mengenai tanda kewibawaan dengan konteks pernikahan Yahudi. Ketika mempelai wanita berjalan menuju ke upacara pernikahan, ia akan tampil dengan tidak mengenakan kerudung, sebagai simbol kebebasan yang masih dimilikinya. Saat tiba di tempat berlangsungnya upacara pernikahan, ia akan mengenakan kerudung sebagai simbol bahwa kini kebebasannya berkurang dan kerudung sebagai wujud hormatnya kepada suaminya. Menurut Cuppert inilah kurang lebih gambaran tanda kewibawaan yang dimaksud Paulus. ${ }^{46}$

Kedua, mengenai malaikat, Barclay berpendapat bahwa malaikat di sini berkaitan dengan kisah Kejadian 6:1-4 tentang "anak-anak Allah" (malaikat) terpikat oleh pesona para perempuan dan mengakibatkan pencemaran atas tujuan penciptaan manusia di mana ketika "anak-anak Allah" ini mengawini anak-anak manusia lahirlah raksasa-raksasa. Kekejian tersebut membuat Allah murka dan sempat menghancurkan dunia dengan air bah. ${ }^{47}$

Dalam pemahaman inilah Paulus menyiratkan dalam perkataannya bahwa ketika seorang perempuan berdoa dan bernubuat, yang hadir bukan hanya para laki-laki di jemaat tetapi juga mengundang kehadiran malaikat-malaikat - yang dalam pemikiran Yahudi semua malaikat adalah lakilaki. Oleh sebab itu perempuan harus mengenakan tanda wibawa yaitu kerudung agar baik para lelaki maupun para malaikat tidak tergoda. ${ }^{48}$ Sementara itu Pfitzner mengusulkan tafsiran yang berbeda mengenai malaikat ini. Menurutnya yang lebih relevan adalah pemikiran seperti yang juga ditemukan pada Naskah Laut Mati, bahwa para malaikat adalah pengawal-pengawal ketertiban dalam ibadah. Jadi dengan mengenakan kerudung, menurut Pfitzner, perempuan mengakui bahwa ia adalah bagian dari tatanan ilahi yang diawasi oleh para malaikat. ${ }^{49}$

Pada ayat 11-12 Paulus menekankan ke-salingtergantung-an antara laki-laki dan perempuan. Tanpa laki-laki tak ada perempuan, tanpa perempuan tak ada laki-laki. Perempuan berasal dari laki-laki, demikian pula laki-laki dilahirkan oleh perempuan. Ini semua berasal dari Allah. Agaknya Paulus mengantisipasi agar jangan terjadi kesalahpahaman tentang perkataannya. Meskipun dalam tertib peribadatan berbeda namun Paulus menekankan bahwa keduanya adalah sama-sama makhluk ciptaan Tuhan. Keduanya saling membutuhkan.

Lalu pada ayat 13-15, Paulus kembali pada argumen awalnya mengenai kesopanan umum dalam peribadatan. Ia memulai dengan pertanyaan retoris, "Pertimbangkanlah sendiri: patutkah perempuan berdoa kepada Allah dengan kepala yang tidak bertudung?". Paulus menujukkan pertanyaan retoris ini kepada orang-orang yang telah mengetahui kehendak Allah dan memiliki akal sehat, dengan harapan jawaban mereka adalah "tidak patut".

Paulus menanyakan pertanyaan retoris lainnya dengan menggunakan alam untuk mendukung pendapatnya. Pertanyaan itu sebenarnya mengandung sebuah gagasan bahwa alam sudah menetapkan laki-laki layaknya berambut pendek dan perempuan berambut panjang. Jika sebaliknya maka hinalah dia. Rambut panjang bagi wanita adalah kehormatan dan rambut pendek bagi laki-laki itulah kehormatannya. Inilah hukum alam yang pada konteks masa itu adalah relevan.

Dikatakan rambut panjang diberikan pada perempuan sebagai penudung. Inilah yang mendukung pendapat beberapa penafsir bahwa tudung yang dimaksudkan Paulus sebenarnya adalah

\footnotetext{
${ }^{46}$ E. Cuppert, Studies in I Corinthians ( London : Stephward Press, 1980), 77

${ }^{47}$ Getty, "I Korintus", 296

${ }^{48}$ William Barclay, Pemahaman Alkitab Setiap Hari : Surat 1 dan 2 Korintus, Jakarta : BPK Gunung Mulia, 2008, 179

${ }^{49}$ Pfitzner, Kesatuan Dalam Kepelbagaian, 205
} 
panjang atau tatanan rambut. Schenk berpendapat bahwa penekanan Paulus di sini bukanlah tudung yang dibicarakan selama ini adalah rambut atau kerudung. Penekanan Paulus adalah bahwa Tuhan telah terlebih dulu menudungi kepala perempuan dengan rambut yang panjang. Ini dimaksudkan agar perempuan senantiasa menudungi kepalanya. ${ }^{50}$

Menurut David J. Lull, kebanyakan penafsir mengasumsikan ayat ke 16 dengan merujuk pada kebiasaan para perempuan yang tidak menggunakan tudung kepala itu. Namun para penafsir lainnya berpendapat bahwa Paulus sebenarnya menegaskan bahwa tidak diizinkan adanya kebiasaan berbantah dalam jemaat Allah. ${ }^{51}$ Schenk juga berpendapat bahwa Paulus bermaksud menunjukkan bahwa itu bukanlah cara jemaat Kristen untuk memecah seperti itu. Orang Kristen bukanlah orang-orang yang harus bertarung demi kepentingannya atau demi mempertahankan haknya sendiri. ${ }^{52}$

\section{Implikasi Tafsir I Korintus 11:2-16 Terhadap Etika Berbusana dalam Beribadah}

Akhir-akhir ini, soal busana yang etis saat beribadah sesungguhnya masih menjadi hal yang penting dalam norma-norma kesopanan. Tentu hal ini bersifat relatif, sebab apa yang dianggap sopan dan pantas di satu wilayah belum tentu sama di wilayah lain. Tetapi ada kesamaan dengan pergumulan dalam konteks jemaat Korintus, yaitu seharusnya dalam beribadah etika dalam berpakaian harus menjadi pertimbangan setiap orang. Bagaimana paradigma etika Kristen dalam perikop I Kor. 11:2-16 dapat digunakan untuk memaknai etika berbusana dalam ibadah online di masa pandemi? Perikop yang telah diuraikan di atas berkaitan dengan pakaian dan juga sikap dalam beribadah. Meskipun konteks dan maksud dari Paulus tidak sama persis, namun kita dapat menggunakan paradigma etika berbusana saat beribadah yang terkandung di dalamnya.

Sebagaimana telah dikemukakan di awal tulisan ini bahwa dengan adaptasi perubahan pola beribadah minggu yang dilaksanakan secara online di rumah atau lokasi berada masing-masing, muncul kebingungan soal kepantasan sikap tubuh dan busana saat beribadah. Sebagian orang merasa bahwa karena dilakukan di rumah sendiri maka tidak perlu mengenakan pakaian yang terlalu formal. Mungkin ada yang hanya mengenakan kaos, mengenakan celana pendek, bahkan mengenakan daster.

Poinnya sebenarnya bukan pada materi yang digunakan saat beribadah melainkan motivasi dari sikap yang mengalami degradasi. Banyak hal yang perlu dikompromikan di masa Pandemi agar peribadahan bisa menyesuaikan dengan kebiasaan baru di masa Normal. Dalam konteks darurat secara temporer dapat dimengerti. Tetapi jika terlalu banyak hal yang dikompromikan, disesuaikan, disederhanakan bukan karena darurat melainkan karena sikap mental yang mengampangkan, menyepelekan, tentu hal ini bisa berdampak mengurangi esensi dan nilai sakral dan kekhidmatan dalam beribadah.

Perikop I Kor.11:2-16 dimaksudkan oleh Paulus untuk menegur ketidakketertiban dalam pelaksanaan ibadah, khususnya yang dilakukan oleh para perempuan yang tidak berkerudung dalam berdoa dan bernubuat. Pembangkangan para perempuan itu tidak hanya sekadar soal busana, tetapi juga berlanjut dalam sikap melaksanakan ibadah. Karakter egoisme dan individualistis adalah hal yang diperangi Paulus dibalik penegasan mengenai etika berbusana dalam ibadah. Dalam konteks berbusana saat ibadah online, hal keteraturan juga perlu diperhatikan. Memang tidak ada standard yang baku untuk menentukan busana seperti apa yang tepat digunakan saat seseorang atau suatu keluarga melakukan ibadah online. Pilihan busana memang sangat relatif. Tapi pilihan busana juga berkaitan dengan pertimbangan etis seseorang. Ketika seseorang beribadah ke gereja (sebelum masa Pandemi misalnya), dari rumah ia memilih pakaian yang rapi, bersih, berdandan dengan baik dan pantas. Ada kemungkinan hal ini ia lakukan karena ia ingin mencerminkan citra yang positif terhadap orang lain di sekitarnya. Mungkin pula pertimbangannya bersifat vertikal yaitu ia ingin menghormati hadirat Allah saat ia beribadah. Artinya pakaian beribadah bahkan sikap dalam beribadah itu mencerminkan jati dirinya.

Ketika seseorang atau suatu keluarga beribadah online, prinsip yang sama harusnya juga digunakan, yaitu pakaian beribadah dan sikap dalam beribadah mencerminkan siapa saya di hadapan Tuhan. Sikap mengupayakan keteraturan, kesopanan, dan sikap yang khidmat saat beribadah sendirian

\footnotetext{
${ }^{50}$ Schenk, $1 \& 2$ Corinthians, 163

${ }^{51}$ David J. Lull, 1 Corinthians : A Commentary For Today (St. Louis : Chalice Press, 2007), 98

52 Schenk, $1 \& 2$ Corinthians, 2006, 163
} 
atau dalam jumlah yang terbatas dalam keluarga - tanpa harus ditentukan oleh ruang publik atau pendapat orang banyak - adalah cara membentuk karakter berdasarkan kebajikan internal.

Perikop I Korintus 11:2-16 memang banyak mengaitkan etika berbusana dalam ibadah dengan konteks sosial yaitu norma kesopanan dan kelaziman busana perempuan di tempat umum, termasuk dalam ruang ibadah. Namun selain itu, Paulus juga mengajarkan bahwa saat beribadah sesungguhnya yang hadir bukan saja manusia melainkan juga para malaikat yang mengawasi ibadah. Dengan adanya peribadahan tercipta situasi yang sakral. Sikap termasuk pakaian seyogyanya menghormati kesakralan itu. Hal ini juga kiranya berlaku dalam ibadah-ibadah minggu di masa kini, bahkan dalam ibadah yang dilakukan secara online.

Ketika ibadah online dilaksanakan sendirian atau bersama keluarga sendiri, kadang ada pemikiran bahwa aktifitas itu tidak dilihat orang lain atau karena kedekatan dengan keluarga lantas dirasa tidak terlalu perlu untuk berpenampilan sebagaimana kalau beribadah ke gereja. Demikian pula dirasa tidak perlu mengikuti sikap-sikap liturgis yang sebagaimana biasanya dilakukan di gedung gereja. Ada dua kemungkinan mengapa pemikiran ini muncul. Pertama karena soal busana dan sikap fisik hanya perlu "lebih diatur" saat bersama orang banyak. Kedua karena merasa ruang yang lebih sakral dan pantas untuk tampil secara rapi dan formal adalah gedung gereja sedangkan rumah tidak memenuhi kriteria kesakralan. Akan tetapi dengan menyimak penjelasan Paulus, mengenai busana dan sikap beribadah, diyakini ruang sakral itu hadir saat orang percaya memutuskan beribadah. Dalam peribadahan itu Allah hadir dan menyertai. Dengan demikian, mengusahakan sikap fisik yang tepat dan busana yang rapi, sopan, dan baik adalah tetap penting

\section{KESIMPULAN}

Kembali kepada pertanyaan penelitian di awal, pertama mengenai bagaimana persoalan busana dalam beribadah dipahami melalui penafsiran terhadap perikop I Korintus 11:2-16. Paulus dalam upaya menasihatkan agar terciptanya keteraturan dalam peribadahan jemaat Korintus menekankan pembedaan antara busana laki-laki dan perempuan dalam peribadahan, yaitu laki-laki tanpa kerudung dan perempuan dengan kerudung. Penekanan ini pertama-tama berdasarkan aspek sosial di mana adalah lazim sesuai kebiasaan pada zaman itu untuk seorang perempuan menggunakan kerudung di depan umum. Dalam konteks sosial masa itu, khususnya bagi perempuan menikah yang berkerudung menandakan ia tidak lagi bebas seperti seorang gadis. Penutup kepala para perempuan di satu sisi merupakan tanda wibawa seorang wanita. Di sisi lain menutup kepala atau tepatnya rambut, adalah cara yang diyakini pada masa itu untuk mencegah terpikatnya para lelaki.

Penekanan pembedaan cara berbusana dalam beribadah antara laki-laki dan perempuan juga didasarkan pada pemahaman teologis yaitu perempuan yang berkerudung menghargai kekepalaan lakilaki yang merupakan gambaran dan pancaran kemuliaan Allah. Pemahaman ini tidak dimaksudkan untuk menunjukkan inferioritas kaum perempuan melainkan untuk menunjukkan tetap berlakunya pembedaan berdasarkan tatanan penciptaan tanpa harus mengakibatkan perbedaan kualitas peran dalam fungsi peribadahan. Pemahaman teologis lainnya yang dikemukakan oleh Paulus ialah, dalam peribadahan para malaikat juga hadir. Adalah penting bagi perempuan untuk menggunakan kerudung sebagai wujud penghormatan terhadap para malaikat. Tidak menggunakan kerudung dipandang sebagai pelanggaran terhadap kesopanan beribadah atau penghinaan terhadap kekepalaan suami, yang mana hal ini tidak disukai oleh para Malaikat yang turut hadir menjaga keutuhan tatanan beribadah. Hal ini menunjukkan adanya perhatian terhadap pentingnya etika berpakaian dalam beribadah pada jemaat mula-mula. Etika tersebut dimaknai berdasarkan konteks sosial dan juga secara teologis. Meskipun tidak bisa diterapkan secara persis dengan konteks masa kini, dapat disimpulkan bahwa pada masa kini tetap perlu ada perhatiaan pada kepantasan berpakaian dalam beribadah.

Pertanyaan penelitian berikutnya ialah terkait bagaimana tinjauan eksegesis terhadap I Korintus 11:2-16 dapat dimaknai dalam konteks etika beribadah online di masa Pandemi. Paulus menekankan agar dalam suatu ibadah harus terwujud keteraturan dan kesopanan. Hal ini dapat dimaknai serupa dalam kesempatan beribadah secara online, baik saat dilaksanakan seorang diri ataupun bersama keluarga dalam jumlah terbatas. Sikap menyepelekan ibadah online dengan anggapan tidak sederajat dengan ibadah di gedung gereja bisa mengakibatkan seseorang memilih busana dengan tidak mempertimbangkan aspek kerapian, keindahan, dan kepantasan. Begitu pula sikap tubuh dalam mengikuti liturgi ibadah bisa jadi tidak cukup hormat atau taat mengikuti arahan yang ada. Meskipun tidak dilihat oleh orang lain, namun etika berpakaian dan sikap tubuh dalam beribadah berkaitan dengan 
etika karakter. Sikap hormat dan sopan serta busana yang rapi dalam beribadah online mencerminkan karakter yang baik dan sikap iman yang penuh hormat kepada Tuhan. Untuk itu perlu dibedakan antara sekadar menonton kegiatan ibadah dengan mengikuti ibadah online. Apabila mengikuti ibadah online kita patut memperhatikan etika berbusana dan sikap tubuh dalam beribadah sebagai wujud penyembahan yang berkenan di hadapan Tuhan. 


\section{DAFTAR PUSTAKA}

Barclay, William. Pemahaman Alkitab Setiap Hari : Surat 1 dan 2 Korintus. Jakarta : BPK Gunung Mulia, 2008.

Cuppert, E. Studies in I Corinthians. London : Stephward Press, 1980.

Duyverman, M.E. Pembimbing Ke Dalam Perjanjian Baru. Jakarta : BPK Gunung Mulia, 2009.

Duha, Asni Darmayanti. "Etika Berpakaian bagi Kaum Perempuan Dalam Ibadah Menurut I Timotius 2:9-10 dan Aplikasinya Masa Kini”. Jurnal Teologi Berita Hidup. Vol.2 No.2. Maret 2020.

Farahiyah, Nurul. "Etika Berbusana : Studi Kontemporer Antara Islam dan Kristen". Skripsi. Fakultas Dakwah dan Komunikasi. Universitas Islam Negeri Ar-Raniry, 2018.

Hurly, James B. Man and Woman In Biblical Perspective. Leicester: Inter-Varsity Press, 1981.

Getty, Marry Ann. "I Korintus”. terj. A.S. Hadiwiyata. Tafsir Alkitab Perjanjian Baru. Yogyakarta : Kanisius, 2002.

Lull, David J. 1 Corinthians : A Commentary For Today. St. Louis : Chalice Press, 2007.

Novalina, Martina. Mengenal Paulus dan Teologinya. Bogor : CV. Lindan Bestari, 2020.

Pfitzner, V.C. Kesatuan Dalam Kepelbagaian: Ulasan atas I Korintus. Jakarta: BPK Gunung Mulia, 2008.

Riedel, K. Tafsir Perjanjian Baru. Yogyakarta : Kanisius, 2008.

Schenk, Kenneth. 1\&2 Corinthians :A commentary for Bible Students. Indianapolis: Wesleyan Publishing House, 2006.

Wahono, S. Wismoady. Di Sini Kutemukan : Petunjuk Mempelajari dan Mengajarkan Alkitab. Jakarta : BPK Gunung Mulia, 2009.

Zaluchu, Sonny Eli. "Eksegesis Kisah Para Rasul 2:42-47 untuk Merumuskan Ciri Kehidupan Rohani Jemaat Mula-mula di Yerusalem". EPIGRAPHE: Jurnal Teologi dan Pelayanan Kristiani. Vol 2 No. 2. November 2018.

\section{B. Sumber Dari Internet}

Arnani, Mela. Update Corona Dunia: 45,2 Juta Kasus Positif, https://www.kompas.com/tren/read/2020/10/30/064800565/update-corona-dunia--45-2-juta-

kasus-positif-rekor-baru-kasus-harian-global?page=all. diakses 30 Oktober 2020

Chrysna, Mahatma. Kepres Penetapan Wabah Covid-19 Sebagai Bencana Nasional, https://kompaspedia.kompas.id/baca/data/dokumen/keppres-penetapan-wabah-covid-19sebagai-bencana-nasional. diakses 30 Oktober 2020

"Panduan Ibadah Online Gbt Alfom Dan Yepo", dalam https://www.youtube.com/watch?v=hjj2uBgRgUE. diakses 25 Januari 2021.

"Panduan Ibadah Online", dalam https://www.youtube.com/watch?v=akM9CTB4H04, diakses 25 Januari 2021. 
"Panduan Mengikuti Ibadah Online", dalam https://www.youtube.com/watch? $=N M 3 L N d U Q p Y g$. diakses pada 25 Januari 2021.

"Petunjuk Praktis Mengikuti Misa Via Online - Keuskupan Agung Jakarta", dalam https://www.youtube.com/watch?v=nD9R8ldnfTE. diakses pada 25 Januari 2021.

"Sikap Saat Ibadah Online", dalam https://www.youtube.com/watch?v=yNOuaVq7bss. diakses 25 Januari 2021. 